\title{
Preface to the Meaning of Moods
}

\author{
Angelika Krebs ${ }^{1} \cdot$ Aaron Ben-Ze'ev $^{2}$
}

Received: 26 July 2017 / Accepted: 26 July 2017 /

Published online: 7 October 2017

(C) Springer Science+Business Media B.V. 2017

Keywords Moods · Emotions · Stimmung · Heidegger - Bollnow · Kambartel · Atmosphere · Meaning · Collective moods · Aesthetics · Harmony · Soul · Religion · Existential feelings $\cdot$ Feelings of being

Moods or Stimmungen play a vital role in our happiness. Yet the category of moods is understudied, despite its relevance. In recent years, however, there has been a surge of interest in the theory of moods, not only in phenomenology (Griffero 2014; Ratcliffe 2008; Fuchs 2000; Schmitz 1998; Böhme 1995), in literary studies (Reents 2015; Reents and Meyer-Sickendiek 2013; Gisbertz 2011; Gumbrecht 2011; Wellbery 2003) and in psychology (Frijda 1993; Thayer 1989), and especially in psychopathology and neuropsychology (Damasio 1995), but also in philosophy in general (Breidenbach and Docherty 2018; Kenaan and Ferber 2011; André 2009; Goldie 2000).

The 22 articles in this philosophical collection explore the meaning of moods under five headings: 1 . What moods are; 2 . Heidegger on moods; 3 . Moods and the meaning of life; 4. Collective moods; and 5. Aesthetics and moods. Most of the articles originated from a workshop held by the European Philosophical Society for the Study of Emotions at Landgut Castelen near Basel in 2015. Only a few papers were added later. Among them are Otto Friedrich Bollnow's article on the nature of moods (originally from 1941) and Friedrich Kambartel's essay on calmness (originally from 1989). Both texts appear here for the first time in English translation. All the papers, except those by Bollnow and Kambartel, have undergone a regular Philosophia refereeing procedure during which they were revised on grounds of reviewers' comments.

Angelika Krebs

angelika.krebs@unibas.ch

Aaron Ben-Ze'ev

abenzeev@univ.haifa.ac.il

1 Departement Künste, Medien, Philosophie, Philosophisches Seminar, Universität Basel,

Steinengraben 5, 4051 Basel, Switzerland

2 Department of Philosophy, University of Haifa, Haifa, Israel 
The collection begins with two central chapters from Bollnow's book Das Wesen der Stimmungen (The nature of moods). Although Martin Heidegger first explored the philosophical significance of Stimmungen and worked out their fundamental importance for our being-in-the-world, Bollnow's work is the classical text on moods, at least in German-language philosophy. Bollnow goes beyond Heidegger's fixation on one mood only, namely Angst or anxiety, and presents a balanced account of the entire variety of sad and happy moods.

As Bollnow explains, drawing on Heidegger, moods constitute the simplest and most original form in which human life comes to know itself. One best understands them in contrast to emotions in the narrow sense; such emotions are always intentionally directed towards a specific object. Moods do not have any specific object; they are states of being, structuring and coloring human existence as a whole.

Every mood, Bollnow continues, is a harmony (Übereinstimmung) between, first, the inner and outer world; second, the states of the body and the soul; and, third, the individual faculties of the soul, all of which are tuned to a uniform base tone. Because moods still live entirely in this unseparated unity of self and world, Bollnow argues that it is incorrect to account for moods solely on a subjective basis and to assume that they subsequently "rub off" on the world.

And, we might add, this is part of the reason why the German term Stimmung is virtually untranslatable into English and is retained in the original German in the translation of Bollnow's chapters in this volume. Stimmung refers to both mood and atmosphere, while in English "mood" belongs on the subjective side and "atmosphere" refers to the state of the world, such as a landscape in spring or a candlelit room.

To lend more plausibility to his central claim about moods as the foundation of the soul, Bollnow distinguishes between two types of moods: first, transient, unsteady, or "moody" moods (Launen), and second, persistent or basic moods (Grundstimmungen). Mood in English is closer to the first type, while Stimmung in German applies equally to both types.

Furthermore, mood in English has a sentimental ring. Yet Bollnow already differentiated between sentimental and non-sentimental moods: sentimental moods are, in a peculiar inversion of the natural perspective, pursued for their own sakes; in this selfgratifying form, they remain infertile and can corrupt the healthy life of the soul.

It is the non-sentimental, basic, subjective moods that are the major focus of this collection. Some of the articles engage directly with Bollnow's view, while others go back to Heidegger, Sartre, Wittgenstein, and Hegel, or approach the topic in a strictly systematic manner, either in general terms or with regard to more specific issues such as religious or mystical attitudes towards life, the individuality or collectivity of moods, and the expression of moods in film and literature.

\section{References}

André, C. (2009). Les états d'âme. Paris: Odile Jacob, English: (2012). Feelings \& Moods. Cambridge: Polity. Böhme, G. (1995). Atmosphäre. Frankfurt: Suhrkamp.

Bollnow, O. F. (1995). Das Wesen der Stimmungen. Frankfurt: Vittorio Klostermann.

Breidenbach, B., \& Docherty, T. (2018). Mood: Aesthetics, Psychology, Philosophy. London: Routledge.

Damasio, A. (1995). Descartes 'Error. London: Picador. 
Frijda, N. H. (1993). Moods, Emotion Episodes, and Emotions. In M. Lewis \& J. M. Haviland (Eds.), Handbook of Emotions (pp. 381-403). New York: Guilford.

Fuchs, T. (2000). Leib, Raum, Person. Stuttgart: Klett-Cotta.

Gisbertz, A.-K. (2011). Stimmung. München: Fink.

Goldie, P. (2000). The Emotions. Oxford: Clarendon Press.

Griffero, T. (2014). Atmospheres. London: Routledge.

Gumbrecht, H. U. (2011). Stimmungen lesen. München: Hanser, English: (2012). Atmosphere, Mood, Stimmung. Stanford: Stanford University Press.

Kenaan, H., \& Ferber, I. (Eds.). (2011). Philosophy's Moods. Berlin: Springer.

Ratcliffe, M. (2008). Feelings of Being. Oxford: Oxford University Press.

Reents, F. (2015). Stimmungsästhetik. Göttingen: Wallstein.

Reents, F., \& Meyer-Sickendiek, B. (Eds.). (2013). Stimmung und Methode. Tübingen: Mohr Siebeck.

Schmitz, H. (1998). Der Leib, der Raum und die Gefühle. Ostfeldern: Arcaden.

Thayer, R. (1989). The Biopsychology of Mood and Arousal. Oxford: Oxford University Press.

Wellbery, D. Barck K., Fontius M., Schlenstedt D., Steinwachs B., Wolfzettel F. (2003). Stimmung. In K. Barck et al. (Eds.), Ästhetische Grundbegriffe (5th ed., pp. 703-733). Stuttgart: Metzler. 